\title{
Pleasure and suffering among hospital nurses
}

\author{
Prazer e sofrimento entre enfermeiros do contexto hospitalar \\ Placer y sufrir entre enfermeras hospitalarias
}

Cláudia Jeane Lopes Pimenta'
ORCID: 0000-0002-1458-8226

Thaíse Alves Bezerra'

ORCID: 0000-0003-3242-4468

Kaisy Pereira Martins' ORCID: 0000-0003-3276-1675

Tatiana Ferreira da Costa' ORCID: 0000-0002-6448-4302

Lia Raquel de Carvalho Viana' ORCID: 0000-0002-4220-906X

Marta Miriam Lopes Costa' ORCID: 0000-0002-2119-3935

Kátia Neyla de Freitas Macedo Costa' ORCID: 0000-0003-2054-6943

'Universidade Federal da Paraíba. João Pessoa, Paraíba, Brazil.

How to cite this article: Pimenta CJL, Bezerra TA, Martins KP, Costa TF, Viana LRC, Costa MML, et al. Pleasure and suffering among hospital nurses. Rev Bras Enferm. 2020;73(2):e20180820. doi: http://dx.doi.org/10.1590/0034-7167-2018-0820

\section{Corresponding Author:}

Cláudia Jeane Lopes Pimenta E-mail: claudinhajeane8@hotmail.com

EDITOR IN CHIEF: Dulce Aparecida Barbosa ASSOCIATE EDITOR: Fátima Helena Espírito Santo

Submission: 10-23-2018 Approval: 07-28-2019

\section{ABSTRACT}

Objectives: to associate pleasure and suffering indicators with aspects related to nursing work in hospitals. Methods: This is a cross-sectional quantitative study conducted with 152 nurses from a university hospital in the city of João Pessoa, Paraíba State, Brazil. Data were collected through interviews, using a tool to obtain sociodemographic data, work characteristics and the Pleasure and Suffering Indicators at Work Scale. Results: pleasure living and its domains were rated as satisfactory, while suffering factors and their domains were critically assessed. Statistically significant associations were observed among pleasure and suffering indicators, and some characteristics of nurses' work. Conclusions: it was evidenced that nurses had critical levels of suffering at work associated with their work practice characteristics.

Descriptors: Nursing; Work; Working Environment; Hospitals; Occupational Health.

\section{RESUMO}

Objetivos: associar os indicadores de prazer e sofrimento com os aspectos relacionados ao trabalho de enfermagem no contexto hospitalar. Métodos: trata-se de um estudo transversal, com abordagem quantitativa, realizado com 152 enfermeiros de um hospital universitário em João Pessoa, Paraíba, Brasil. Os dados foram coletados por meio de entrevistas, mediante a utilização de um instrumento para obtenção dos dados sociodemográficos, e características do trabalho e da Escala de Indicadores de Prazer e Sofrimento no Trabalho. Resultados: a vivência de prazer e os seus domínios foram classificados como satisfatórios, enquanto os fatores de sofrimento e seus domínios obtiveram avaliação crítica. Foram observadas associações estatisticamente significativas entre os indicadores de prazer e sofrimento, e algumas características do trabalho dos enfermeiros. Conclusões: foi evidenciado que os enfermeiros apresentavam níveis críticos de sofrimento no trabalho, associados às características de sua prática laboral.

Descritores: Enfermagem; Trabalho; Ambiente de Trabalho; Hospitais; Saúde do Trabalhador.

\section{RESUMEN}

Objetivos: asociar indicadores de placer y sufrimiento con aspectos relacionados con el trabajo de enfermería en el hospital. Métodos: este es un estudio transversal y cuantitativo realizado con 152 enfermeras de un hospital universitario en la ciudad de João Pessoa, estado de Paraíba, Brasil. Los datos fueron recolectados a través de entrevistas, utilizando un instrumento para obtener datos sociodemográficos, características del trabajo y la Escala de Indicadores de Placer y Sufrimiento en el Trabajo. Resultados: la experiencia del placer y sus dominios se clasificaron como satisfactorios, mientras que los factores de sufrimiento y sus dominios obtuvieron una evaluación crítica. Se observaron asociaciones estadísticamente significativas entre los indicadores de placer y sufrimiento, y algunas características del trabajo de las enfermeras. Conclusiones: se evidenció que las enfermeras tenían niveles críticos de sufrimiento en el trabajo, asociado con las características de su práctica laboral.

Descriptores: Enfermería; Trabajo; Ambiente de Trabajo; Hospitales; Salud Laboral. 


\section{INTRODUCTION}

Work has suffered several impacts caused by changes in beliefs and values in the modern and globalized world, generating a restructuring process in the way it is organized ${ }^{(1)}$. These transformations had a significant impact on the health and nursing sector, and were characterized by increased pace, work hours and competitiveness, low pay with multifunctionality, inadequate sizing of professionals and strengthening of individualism, which can interfere with workers' health ${ }^{(2)}$.

The performance of nurses can cause distress and intense suffering due to their exposure to occupational risks ${ }^{(3)}$. A study conducted in Iran showed that most of the nurses' workplaces are inadequate, as they have precarious working conditions, with excessive patients, high levels of violence, low wages, material deficiency and high turnover ${ }^{(4)}$. However, in developed countries, especially in Europe, nursing work has characteristics that favor greater satisfaction, such as high wages, technical and decision-making autonomy, presence of healthy work environments, recognition for the services provided and incentive for professional qualification ${ }^{(5-7)}$.

The dynamics related to the work process of nurses are not limited to the physical space where their activities are developed, but also encompassing complex, multifactorial and interrelated elements. These elements are communication between the team, the individual's understanding of their role and function, organizational support and social support received, daily work intensity and pace, power relations, and the availability and quality of care resources. These are aspects that can significantly interfere with workers' health ${ }^{(8)}$.

Although each service has specificities that differ according to the level of attention provided, some elements are relevant to guide the performance of work practices, such as adequate physical area, sufficient equipment and materials, qualified human resources and the establishment of standards, routines and protocols $s^{(9)}$. However, the precariousness of working conditions in nursing is very frequent, especially in the hospital environment, causing damage to the health of the professional, as well as increased occupational risks ${ }^{(10)}$.

The characteristics of the practice of this profession are also potential causes of negative experiences, due to daily contact with suffering, pain and death, requiring a high psychic control to deal adequately and humanely with each situation ${ }^{(11)}$. However, work practice is understood as a transforming element of reality, in which suffering often represents a fundamental condition to drive the worker to create strategies to overcome adversity, enabling the feeling of pleasure ${ }^{(12)}$.

Furthermore, it is relevant to investigate the experiences of pleasure and suffering in the workplace, as they have the potential to negatively affect the health condition of nurses, as well as causing damage to the quality and safety of patient care ${ }^{(6)}$. There is a lack of studies assessing the relationship between the characteristics of nursing work and the experience of pleasure and suffering in hospitals in general, often restricted to specific and highly complex sectors such as oncology, orthopedics and Intensive Care Unit (ICU) $(6,10)$.

Nevertheless, investigating these factors in the work of nurses can provide an understanding of the elements that positively and negatively influence their practices, allowing the development of strategies for the promotion of a more pleasant space that promotes quality of care and patient safety during care ${ }^{(11)}$.

\section{OBJECTIVES}

To associate pleasure and suffering indicators with aspects related to nursing work in hospitals.

\section{METHODS}

\section{Ethical aspects}

This study followed Resolution 466/2012 of the Brazilian National Health Board (Conselho Nacional de Saúde), and was approved by the Research Ethics Committee. Participants were duly informed about the justification of the research, its purpose, risks and benefits, procedures to be performed, guarantee of confidentiality and confidentiality of the information provided, and signed the Free Informed Consent Term.

\section{Design, place of study, and period}

This is a cross-sectional quantitative study conducted in a university hospital located in the city of João Pessoa, Paraíba State, Brazil, between October and November 2017.

\section{Population and sample; inclusion and exclusion criteria}

The study population was composed of all nurses working in the referred hospital. The sample calculation was based on the number of professionals with undergraduate nursing degree registered in the Brazilian National Register of Health Facilities (Cadastro Nacional de Estabelecimentos de Saúde) of the Brazilian Unified Health System (Sistema Único de Saúde), referring to the institution staff, totaling 252 nurses. Sample size was defined using the calculation for finite populations of known proportions based on a margin of $5 \%$ error (Error $=0.05$ ), with $95 \%$ reliability degree ( $a=0.05$ that provides $Z_{0,05 / 2}=1.96$ ), considering the proportion of participants of $50 \%(p=0.5)$, totaling 152 nurses.

Inclusion criteria were defined as having an active employment relationship with the hospital and having been working as a nurse in this service for at least six months. Exclusion criteria were defined as being on vacation, sick leave or maternity leave during the data collection period.

\section{Study protocol}

Data were collected through interviews, using an instrument to obtain data regarding sociodemographic data and the work characteristics of nurses and the Pleasure and Suffering Indicators at Work Scale (PSIWS) ${ }^{(8)}$. PSIWS is part of the Work Inventory and Illness Risks (Inventário sobre Trabalho e Riscos de Adoecimento), a self-applicable scale validated in Brazil in 2007, which is composed of three other tools: Work Context Assessment Scale, Human Labor Cost Scale and Work-Related Damage ${ }^{(8)}$.

It is a scale with 32 questions that present Likert-type answer options, which assesses the occurrence of pleasure and suffering 
indicators in the last six months of work, ranging from 0 (no time) to 6 (six or more times), comprising four factors: Freedom of Speech, Professional Achievement, Burnout and Lack of Recognition ${ }^{(8)}$.

\section{Analysis of results, and statistics}

The analysis was performed from the mean among items, being classified in three different levels. For the factors that assess pleasure (items 1 to 17), indicators are classified as positive, satisfactory (score $\geq 4.0$ ); moderate or critical (scores between 3.9 and 2.1); assessment for rarely severe (score $\leq 2.0)$. For factors that assess suffering at work (items 18 to 32 ), indicators are classified as most negative, severe $\geq 4$; moderate or critical assessment between 3.9 and 2.1; less negative, satisfactory rating $\leq 2.0^{(8)}$.

The collected data were compiled and stored in the Microsoft Office Excel program and later imported into the Statistical Package for the Social Sciences (SPSS) version 22.0. To verify the normality / symmetry of the numerical data, the Kolmogorov-Smirnov test was used. The maximum significance level used was $5 \%(p \leq 0.05)$. Factors reliability was assessed by using Cronbach's alpha coefficient. The Mann-Whitney and Kruskal-Wallis tests were used to associate the variables.

\section{RESULTS}

A total of 152 nurses participated in this study, with a higher prevalence of females (91.4\%), aged between 30 and 39 years $(48.0 \%)$ and mean age of 39.3 years $( \pm 0.96)$. married or with a stable union (62.5\%), practitioners of some religion ( $98.7 \%)$, with personal income between 5,000 and 7,999 reais (reais is a Brazilian currency; 5,000 and 7,999 reais are about 1,250 and 2,000 US dollars) (65.1\%) and living with one to two people (42.8\%).

When assessing the nurses' work activity, it is observed that Pleasure and Professional Achievement and Freedom of Speech were classified as satisfactory, while Suffering and the lack of Recognition obtained critical assessment. The scale showed good internal reliability, with most Cronbach's Alpha values greater than 0.80 (Table 1).

Pleasure and suffering at work indicators presented a statistically significant association ( $\mathrm{p} \leq 0.05$ ) with the unit/sector and work scale variables. The variables working time in the sector, other employment and training had a significant association $(p \leq 0.05)$ only with suffering at work indicators (Table 2).

Absenteeism characteristics and pleasure and suffering indicators were significantly associated $(p \leq 0.05)$ with the absence at work variable (Table 3).

Table 1 - Pleasure and suffering at nursing work indicators assessment, João Pessoa, Paraíba, Brazil, 2017 (N=152)

\begin{tabular}{llcccc}
\hline Indicator & Factor & Mean & Standard Deviation & Assessment & Cronbach's Alpha \\
\hline \multirow{2}{*}{ Pleasure } & Professional Achievement & 4.2 & 1.326 & Satisfatória & 0.81 \\
& Freedom of Speech & 4.1 & 1.315 & Satisfatória & 0.79 \\
Suffering & Burnout & 2.9 & 1.559 & Crítica & 0.86 \\
& Lack of Recognition & 2.1 & 1.525 & Crítica & 0.87
\end{tabular}

Table 2 - Association between aspects related to nursing work and pleasure and suffering indicators, João Pessoa, Paraíba, Brazil, 2017 (N=152)

\begin{tabular}{|c|c|c|c|c|c|c|}
\hline \multirow{2}{*}{ Variables } & \multicolumn{3}{|c|}{ Pleasure } & \multicolumn{3}{|c|}{ Suffering } \\
\hline & Mean & SD & $p$ value & Mean & SD & $p$ value \\
\hline \multicolumn{7}{|l|}{ Unit/Sector } \\
\hline Outpatient clinic & 4.7 & 0.947 & \multirow{10}{*}{$0.050^{* *}$} & 1.7 & 1.194 & \multirow{10}{*}{$0.021^{* *}$} \\
\hline Obstetric Clinic & 4.6 & 1.560 & & 2.4 & 1.600 & \\
\hline Surgery Center & 4.2 & 1.072 & & 2.2 & 1.355 & \\
\hline Department of Parasitic Infectious Diseases & 4.2 & 0.836 & & 2.4 & 1.657 & \\
\hline Pediatric Clinic & 4.1 & 1.221 & & 2.3 & 1.357 & \\
\hline Material and Sterilization Center & 4.0 & 1.566 & & 2.8 & 1.714 & \\
\hline Medical clinic & 4.0 & 1.261 & & 2.8 & 1.354 & \\
\hline Surgical clinic & 3.8 & 1.372 & & 1.8 & 1.135 & \\
\hline Intensive care unit & 3.8 & 0.922 & & 2.9 & 1.387 & \\
\hline Administrative & 3.7 & 1.287 & & 2.4 & 1.563 & \\
\hline \multicolumn{7}{|l|}{ Working time in the sector } \\
\hline$<1$ year & 4.5 & 1.121 & \multirow{5}{*}{$0.138^{* *}$} & 1.9 & 1.294 & \multirow{5}{*}{$0.007^{* *}$} \\
\hline $1-5$ years & 4.1 & 1.209 & & 2.5 & 1.475 & \\
\hline $6-10$ years & 3.7 & 0.806 & & 3.2 & 1.228 & \\
\hline $11-15$ years & 3.9 & 1.362 & & 3.2 & 1.050 & \\
\hline$>15$ years & 4.4 & 1.666 & & 1.1 & 1.180 & \\
\hline \multicolumn{7}{|l|}{ Other work tie } \\
\hline No & 4.1 & 1.189 & \multirow{2}{*}{$0.676^{*}$} & 2.2 & 1.444 & \multirow{2}{*}{$0.025^{*}$} \\
\hline Yes & 4.1 & 1.227 & & 2.7 & 1.412 & \\
\hline \multicolumn{7}{|l|}{ Work scale } \\
\hline 6 hours & 4.5 & 1.032 & \multirow{4}{*}{$0.002^{* *}$} & 1.9 & 1.310 & \multirow{4}{*}{$0.003^{* *}$} \\
\hline 8 hours & 3.7 & 1.206 & & 2.7 & 1.317 & \\
\hline 12 hours & 4.2 & 1.204 & & 2.4 & 1.600 & \\
\hline Rotation between 6,8 or 12 hours & 3.6 & 1.157 & & 3.0 & 1.284 & \\
\hline \multicolumn{7}{|l|}{ Training } \\
\hline Yes & 4.3 & 1.162 & \multirow{3}{*}{$0.074^{*}$} & 2.1 & 1.382 & \multirow[t]{3}{*}{$0.014^{*}$} \\
\hline No & 4.0 & 1.224 & & 2.7 & 1.470 & \\
\hline Total & 4.1 & 1.203 & & 2.4 & 1.450 & \\
\hline
\end{tabular}


Table 3 - Association between absenteeism characteristics in nursing work and indicators of pleasure and suffering, João Pessoa, Paraíba, Brazil, 2017 (N=152)

\begin{tabular}{|c|c|c|c|c|c|c|}
\hline Variables & Mean & $\begin{array}{c}\text { Pleasure } \\
\text { Standard Deviation }\end{array}$ & $p$ value & Mean & $\begin{array}{c}\text { Suffering } \\
\text { Standard Deviation }\end{array}$ & $p$ value \\
\hline \multicolumn{7}{|l|}{ Work absence } \\
\hline No & 4.5 & 1.087 & \multirow{2}{*}{$0.002^{*}$} & 1.9 & 1.303 & \multirow{2}{*}{$0.000^{*}$} \\
\hline Yes & 3.9 & 1.218 & & 2.8 & 1.437 & \\
\hline \multicolumn{7}{|l|}{ Absence reasons } \\
\hline Medical leave & 4.4 & 0.840 & \multirow{5}{*}{$0.265^{* *}$} & 2.8 & 1.142 & \multirow{5}{*}{$0.279 * *$} \\
\hline Off work & 4.1 & 1.192 & & 2.4 & 1.461 & \\
\hline Personal reason & 3.8 & 1.243 & & 2.9 & 1.442 & \\
\hline Not applicable & 4.5 & 1.087 & & 1.9 & 1.303 & \\
\hline Total & 4.1 & 1.203 & & 2.4 & 1.450 & \\
\hline
\end{tabular}

Note: *Mann-Whitney Test; **Kruskal-Wallis Test.

\section{DISCUSSION}

It was observed that the pleasure at work indicator was satisfactory, however, it was also evidenced critical levels of the factors of suffering. The situations experienced in the work environment may be perceived differently by professionals, positively or negatively affecting their skills, which results in behaviors and consequences that generate distinct encouragement ${ }^{(12)}$.

Work place generates a strong influence on the individual perception of nurses about the development of their activities. Some factors are commonly referred to in the literature as pleasure indicators at work, such as effective communication among team members, recognition, appreciation, freedom to negotiate with the manager, and adequate remuneration for the function performed ${ }^{(6)}$.

In contrast, some elements that exist in nursing practice can also negatively interfere with their activities, causing suffering and dissatisfaction, such as the presence of a hostile environment, high turnover of professionals, low wages and the lack of materials and supplies for care $^{(4)}$. In addition, interpersonal relationships also significantly affect work, especially in the presence of conflicts, which influence the quality and safety of patient care ${ }^{(6)}$.

In this study, work in some hospital units showed a statistically significant association with pleasure and suffering indicators, with the outpatient and obstetric clinic sectors having the highest positive means. Meanwhile, the experiences of suffering were more present among professionals working in the ICU, medical clinic and Material and Sterilization Center (MSC).

Outpatient clinic is a unit that demands a reduced physical effort of the nurse, because the consultations are performed by prior referral, by scheduling the day and time for consultations and / or procedures. Therefore, there is no occurrence of emergency activities with potential risk of death or need for immediate hospitalization ${ }^{(13)}$. For this reason, professionals with health problems or work restrictions, especially older ones, are relocated from more complex sectors to those with less complexity, and this intervention is usually linked to an improvement in quality of life and working conditions ${ }^{(14)}$.

The greatest pleasure in the obstetric clinic means could be justified by the well-being and satisfaction caused by the assistance to women during labor, as a result of the activities performed result in the birth of a new life, bringing happiness to both parents and family and to the team that participated in this process ${ }^{(15)}$.
In critical sectors such as the ICU and the medical clinic, nursing practice is often associated with high rates of suffering and dissatisfaction with work practice. In these environments, professionals perform their activities with an intense work rhythm, high demand for physical effort during patient care and skill requirement to perform the procedures, as well as the need for agility in reasoning for decision-making ${ }^{(16)}$.

ICU is one of the most critical sectors of the hospital, being referred by several authors as the unit in which the professional is subject to greater suffering, be it physical, psychological and/or emotional ${ }^{(17-19)}$. In this environment, several factors are related and can potentiate the suffering experienced. The physical structure itself and organizational characteristics can be negative for workers, such as being indoors, with artificial lighting, where the isolation of the work team occurs and the presence of loud noise and noise caused by the large amount of technological apparatus ${ }^{(20)}$.

The daily work of nursing work in the ICU is marked by an intense and stressful daily routine and highly complex care, with hemodynamically unstable patients, highly dependent and with imminent risk of death. The presence of qualified professionals with technical and scientific knowledge and psycho-emotional skills is essential to deal with the pressure of operating in a sector that must be safe and flawless, given that any mistake can be fatal(20-21).

The performance of nurses in the medical clinic is marked by the performance of tasks with high complexity and the presence of a large number of patients. Most of these patients are partially or completely dependent, and a large amount of time is devoted to direct and indirect care through drug administration, hemodynamic control, vital sign monitoring and hygienic, supportive and care procedures, which can lead to intense burnout and cause suffering in this professional ${ }^{(22-23)}$.

Given this, the complexity of the tasks performed, together with the intense situations experienced in this sector, can contribute to the development of health problems of workers due to the physical, biological, chemical, ergonomic and psychic risks to which nurses are exposed daily, resulting in damage to quality of life and time off work ${ }^{(13)}$.

MSC also presented high means of suffering at work among the investigated nurses. In this unit, professionals are exposed to a high number of occupational risks, such as fast pace, productivity demands and repetitive, fragmented and mechanistic work ${ }^{(24)}$. Other factors that can cause suffering are the devaluation and 
lack of recognition by other professionals. Many regard MSC as a low-complexity sector that does not provide direct patient care, although it plays a key role in patient safety through the prevention and control of nosocomial infections ${ }^{(24)}$.

With regard to working time in the sector, this showed a significant association with suffering indicators. Nurses who worked at the same unit between six and 15 years obtained higher means regarding negative experiences of the environment. This finding could be related to prolonged living with the same work routine, which in many cases can be intense and exhausting ${ }^{(25)}$.

The nursing work routine has a unique dynamics, often associated with the experience of stressful situations and the performance of highly complex procedures with potential risk for both the patient and the professional. Therefore, this can cause a high tension and trigger pathological processes, especially when the worker develops these activities for a long period of time ${ }^{(25)}$.

Another employment relationship showed a significant association with suffering at work indicators. The presence of other work activity results in an excessive workload, causing damage to the worker's personal and professional life, such as the reduction of time devoted to rest, leisure, and family ${ }^{(26)}$. This has a direct influence on health, being evidenced by the high rates of musculoskeletal problems, insomnia, metabolic, hormonal and immunological alterations, mental and behavioral disorders, among others, which can lead to chronic stress and burnout, classified as Burnout Syndrome ${ }^{(27)}$.

Double working hours also compromises the care provided, significantly interfering with the quality of the activities performed and patient and worker safety ${ }^{(28)}$. Studies conducted in hospital settings with health professionals in Alagoas State ${ }^{(29)}$ and with the nursing staff in the Northeast ${ }^{(10)}$ evidenced that the presence of another employment relationship was associated with greater psychological distress, decreased work performance, adoption of risk practices such as self-medication, increased number of occupational accidents, and a higher frequency of errors and failures during care.

Another aspect to consider is the existence of activities that do not constitute a second workday, but require other types of professional skills, such as the completion of postgraduate courses, especially stricto sensu. In university hospitals, there is often the incentive for greater training and improvement of employees, influencing the socioeconomic conditions of the individual and their work practice, with wage increase and professional advancement ${ }^{(30)}$.

In addition to the workload related to work practice, the worker also allocates a large part of his or her free time to fulfill the activities related to the disciplines, internships, orientations and project preparation, dissertation or thesis, which can trigger intense stress, causing or enhancing the suffering experienced in the workplace ${ }^{(26)}$.

Work scale also showed a statistically significant association with pleasure and suffering indicators, in which professionals who worked six hours a day had more positive experiences, referring to daytime work. In contrast, the work schedule, which rotates between six, eight or 12 hours daily, was related to negative feelings for nurses, characterizing the work in very diversified shifts, also working at night.
Day work is a more convenient routine for the majority of the population, since most activities related to an individual's life are performed in the morning. Thus, there is a greater familiarity with this time and, consequently, a greater pleasure in several aspects, including at work ${ }^{(31)}$. A study conducted with nurses from Coronary Care Units in Greece showed that day shift professionals had higher levels of job satisfaction and autonomy when compared to night workers ${ }^{(32)}$.

The definition of the working scale in nursing seeks to provide care maintenance for 24 hours, often occurring without consulting the professional about the time that best suits their development, causing suffering in the individual, especially when there is no fixed work schedule, which interferes with their social and professional life $\mathrm{e}^{(33-34)}$.

Being developed in shifts and divided by different scales, nursing work causes changes in circadian rhythm, stress, moodiness, excessive intake of foods high in sugars and fats, reduction in hours and sleep quality, decreased states alertness and reasoning, in addition to the possibility of developing depression and suicidal tendencies ${ }^{(27)}$.

Training showed a statistically significant association with suffering at work indicators. Nurses who stated that they had not received initial training to work in the hospital sector showed higher means of negative experiences related to their activities.

Training provided during hospital admission and / or working in new sectors is fundamental for the professional to adapt to the specific rules and routines of each unit, as well as providing knowledge of Standard Operating Procedures and the safe handling of equipment and materials, reducing occupational hazards and occupational accidents ${ }^{(31)}$. Moreover, they also have a direct impact on the quality and safety of patient care, as they allow the improvement of knowledge and techniques usually performed by nurses ${ }^{(25)}$.

Training is considered as an important management strategy for the integration of the work team. Training allows the improvement of the relationship between professionals and the formation and strengthening of interpersonal relationships, favoring sharing and discussion about problems and conflicts in the workplace. It also generates a greater commitment of all to find efficient solutions for each situation ${ }^{(31)}$.

The lack of work also had a statistically significant association with pleasure and suffering indicators. Professionals who did not miss work in the last three months prior to data collection had higher means of pleasure indicators, while nurses who were absent from the service had higher means of suffering.

Absenteeism among health professionals is often caused by workers' illness, being considered as a serious organizational problem, significantly interfering with the work dynamics and the quality of the services provided ${ }^{(23)}$. Este fenômeno multifatorial e complexo, repercute diretamente na assistência à saúde do paciente, comprometendo o planejamento, a tomada de decisões e a execução das atividades laborais ${ }^{(35)}$.

A study conducted in a university hospital in France showed that patient satisfaction with the services provided was inversely proportional to the number of absences from work by nurses, justifying that the absence of this professional generates losses for the hospital organization and for customer care ${ }^{(36)}$. 
It is essential that managers promote healthy work environments, minimizing occupational risks and developing strategies for the early identification of situations that may compromise the health and quality of life of professionals ${ }^{(37)}$. Nevertheless, institutions must ensure the health care of their professionals through the direct actions taken by the Specialized Service in Safety Engineering and Occupational Medicine and indirectly by the accident prevention committees ${ }^{(38)}$.

\section{Study limitations}

The limitations of the study are related to the use of the crosssectional method, as it does not allow the identification of the cause and effect relationship between pleasure and suffering indicators and nursing work characteristics.

\section{Contributions to nursing, health or public policy}

The study contributes important data that support nursing management, since management deals with staff sizing, time scales, interpersonal conflicts, training, and worker satisfaction or dissatisfaction. These findings have the potential to favor the development and/or improvement of worker health care programs in hospital services, which may occur through regular monitoring of workload exposure and investigation of burnoutrelated processes.

\section{CONCLUSIONS}

The present study showed that nurses had critical levels of suffering at work, associated with the characteristics of their work practice. The complexity involved in patient care associated with the high demand for activities can cause burnout and illness that tend to aggravate the health condition of the professional, due to daily contact with situations that cause suffering. Negative consequences of nurses' illness are not restricted to the life and health of the professional, affecting the quality and safety of patient services, which, in more severe cases, may result in iatrogenesis, permanent disability or death.

Although the relevance of nursing work at different levels of health care is recognized in much of the world, in Brazil there are still few initiatives that promote the valorization of the profession and a greater attention to the identified weaknesses. Internationally, campaigns are underway to strengthen nursing in the face of current health challenges, especially in relation to education, improving working conditions and the development of innovative and evidence-based practices.

Nurses' satisfaction and well-being are the responsibility of health institutions and the public authorities, through the development and/or improvement of workers' health programs that must be supervised by the Regional Nursing Council (COREN - Conselho Regional de Enfermagem) of each state, in order to ensure the general and individual interests of professionals. In this sense, it is necessary that health services implement strategies aimed at preventing accidents and reducing occupational risks, offering support and psychological monitoring, as well as monitoring burnout processes.

\section{FUNDING}

This study was funded by the Coordination for the Improvement of Higher Education Personnel Coordination - Brazil (CAPES - Coordenação de Aperfeiçoamento de Pessoal de Nível Superior) - Financing Code 001.

\section{REFERENCES}

1. Carvalho AGF, Cunha ICKO, Balsanelli AP, Bernardes A. Authentic leadership and the personal and professional profile of nurses. Acta Paul Enferm. 2016;29(6):618-25. doi: 10.1590/1982-0194201600087

2. Gonçalves FGA, Souza NVDO, Zeitoune RCG, Adame GFPL, Nascimento SMP. Impacts of neoliberalism on hospital nursing work. Texto Contexto Enferm. 2015;24(3):646-53. doi: 10.1590/0104-07072015000420014

3. Felli VEA, Costa TF, Baptista PCP, Guimarães ALO, Anginoni BM. Exposure of nursing workers to workloads and their consequences. Rev EsC Enferm USP [Internet]. 2015;49(esp 2):96-103. doi: 10.1590/S0080-623420150000800014

4. Alilu L, Zamanzadeh V, Valizadeh L, Habibzadeh H, Gillespie M. A Grounded theory study of the intention of nurses to leave the profession. Rev Latino-Am Enferm. 2017;25:e2894. doi: 10.1590/1518-8345.1638.2894

5. Leal JAL, Melo CMM. The nurses' work process in different countries: an integrative review. Rev Bras Enferm. 2018;71(2):413-23. doi: 10.1590/0034-7167-2016-0468

6. Bordignon M, Monteiro MI, Mai S, Martins MFSV, Rech CRA, Trindade LL. Oncology nursing professionals'job satisfaction and dissatisfaction in Brazil and Portugal. Texto Contexto Enferm. 2015;24(4):925-33. doi: 10.1590/0104-0707201500004650014

7. Bellaguarda MLR, Nelson S, Padilha MI, Caravaca-Morera JA. Prescritive Authority and Nursing: a comparative analysis of Brazil and Canada. Rev Latino-Am Enferm. 2015;23(6):1065-73. doi: 10.1590/0104-1169.0418.2650

8. Mendes AM. Psicodinâmica do trabalho: teoria, método e pesquisas. São Paulo: Casa do Psicólogo; 2007.

9. Goulart BF, Coelho MF, Chaves LDP. Nursing staff in hospital attention: integrative review. Rev Enferm UFPE. 2014;8(2):386-95. doi: 10.5205/ reuol.4688-38583-1-RV.0802201421

10. Dias ICCM, Torres RS, Gordon ASA, Santana EAS, Serra MAAO. Factors associated with work accidents in the nursing team. Rev Enferm UFPE. 2017;11(Suppl. 7):2850-5. doi: 10.5205/reuol.11007-98133-3-SM.1107sup201705 
11. Guimarães ALO, Felli VEA. Notification of health problems among nursing workers in university hospitals. Rev Bras Enferm. 2016;69(3):47582. doi: 10.1590/0034-7167.2016690313i

12. Berni LB, Beck CLC, Prestes FC, Silva RM, Bublitz S, Lamb F. Indicators of pleasure/pain in hygiene and cleaning outsourced workers of a university hospital. Rev Rene. 2016;17(2):155-64. doi: 10.15253/2175-6783.2016000200002

13. Marques DO, Pereira MS, Silva e Souza AC, Vila VSC, Almeida CCOF, Oliveira EC. Absenteeism: illness of the nursing staff of a university hospital. Rev Bras Enferm. 2015;68(5):594-600. doi: 10.1590/0034-7167.2015680516i

14. Souza AMN, Teixeira ER. Sociodemographic profile of nursing team at the outpatient clinic of a university hospital. Rev Enferm UFPE. 2015;9(Suppl. 3):7547-55. doi: 10.5205/reuol.7049-61452-1-ED.0903supl201507

15. Bowden MJ, Mukherjee S, Williams LK, DeGraves S, Jackson M, McCarthy MC. Work-related stress and reward: an Australian study of multidisciplinar pediatric oncology healthcare providers. Psychooncology. 2015;24(11):1432-8. doi: 10.1002/pon.3810

16. Azevedo BDS, Nery AA, Cardoso JP. Occupational stress and dissatisfaction with quality of work life in nursing. Texto Contexto Enferm. 2017;26(1):e3940015. doi: 10.1590/0104-07072017003940015

17. Nogueira LS, Ferretti-Rebustini REL, Poveda VB, Silva RCG, Barbosa RL, Oliveira EM et al. Nursing workload: is it a predictor of healthcare associated infection in intensive care unit? Rev Esc Enferm USP. 2015;49(esp):35-41. doi: 10.1590/S0080-623420150000700006

18. Padilha KG, Barbosa RL, Andolhe R, Oliveira EM, Ducci AJ, Bregalda RS et al. Nursing workload, stress/burnout, satisfaction and incidents in a trauma Intensive Care Units. Texto Contexto Enferm. 2017;26(3):e1720016. doi: 10.1590/0104-07072017001720016

19. Andolhe R, Barbosa RL, Oliveira EM, Costa ALS, Padilha KG. Stress, coping and burnout among Intensive Care Unit nursing staff: associated factors. Rev Esc Enferm USP. 2015;49(esp):57-63. doi: 10.1590/S0080-623420150000700009

20. Martins CCF, Dantas MSP, Marinho FP, Almeida LA, Santos VEP. Stressors agents in intensive care: vision of nursing professionals. Rev Enferm UFPE. 2014;8(10):3386-91. doi: 10.5205/reuol.6039-55477-1-ED.0810201417

21. Goulart LL, Carrara FSA, Zanei SSV, Whitaker IY. Nursing workload related to the body mass index of critical patients. Acta Paul Enferm. 2017;30(1):31-8. doi: 10.1590/1982-0194201700006

22. Pias C, Mascolo NP, Rabelo-Silva ER, Linch GFC, Souza EN. Care complexity in the intensive care unit: subsidies for nursing staff dimensioning. Cogitare Enferm [Internet]. 2015 [cited 2018 Mar 11];20(3):531-6. Available from: http://www.saude.ufpr.br/portal/ revistacogitare/wp-content/uploads/sites/28/2016/10/41083-163038-1-PB.pdf

23. Galindo IS, Ferreira SCM, Lazzari DD, Kempfer SS, Testoni AK. Absenteism reasons in an ambulatorial nursing team. Rev Enferm UFPE. 2017;11(Suppl. 8):3198-205. doi: 10.5205/reuol.11135-99435-1-ED.1108sup201702

24. Bittencourt VLL, Banetti ERR, Graube SL, Stumm EMF, Kaiser DE. Experiences of nursing professionals on environmental risks in a Central Sterile Services Department. Rev Min Enferm. 2015;19(4):871-6. doi: 10.5935/1415-2762.20150067

25. Balthazar MAP, Andrade M, Souza DF, Cavagna VM, Valente GSC. Occupational risk management in hospital services: a reflective analysis. Rev Enferm UFPE. 2017;11(9):3482-91. doi: 10.5205/reuol.11088-99027-5-ED.1109201720

26. Magnago TSBS, Prochnow A, Urbanetto JS, Greco PBT, Beltrame M, Luz EMF. Relationship between work ability in nursing and minor psychological disorders. Texto Contexto Enferm. 2017;26(2):e1180015. doi: 10.1590/0104-07072015002580013

27. Cechin P, Freitas HMB, Ilha S, Martins ESR, Souza MHT. Changes experienced by nursing professionals double workday. Rev Enferm UFPE. 2014;8(11):3855-61.doi: 10.5205/reuol.6679-58323-1-ED.0811201406

28. Machado LSF, Rodrigues EP, Oliveira LMM, Laudano RCS, Nascimento Sobrinho CL. Agravos à saúde referidos pelos trabalhadores de enfermagem em um hospital público da Bahia. Rev Bras Enferm. 2014;67(5):684-91. doi: 10.1590/0034-7167.2014670503

29. Maciel MPGS, Santana FL, Martins CMA, Costa WT, Fernandes LS, Lima JS. Use of psychoactive medication between health professionals. Rev Enferm UFPE. 2017;11(Suppl 7):2881-7. doi: 10.5205/reuol.11007-98133-3-SM.1107sup201709

30. Fabriz LA, Bernardino E, Chaves MMN, Peres AM, Utzumi FC, Aued GK. The work of the nurse in the context of transformation: from general hospital to teaching. Rev Enferm UFPE. 2017;11(11):188-95. doi: 10.5205/reuol.9978-88449-6-1101201723

31. Benetti ERR, Kirchhof RS, Bublitz S, Weiller TH, Lopes LFD, Guido LA. Sociodemographic and functional characteristics of nursing workers of a private hospital. Rev Enferm UFPE. 2015;9(1):128-36. doi: 10.5205/reuol.6817-60679-1-ED.0901201518

32. Gouzou M, Karanikola M, Lemonidou C, Papathanassoglou E, Giannakopoulou M. Measuring professional satisfaction and nursing workload among nursing staff a Greek Coronary Care Unit. Rev Esc Enferm USP. 2018;49(spe):15-21. doi: 10.1590/S0080-6234201500000003

33. Silva RM, Zeitoune RCG, Beck CLC, Martino MMF, Prestes FC, Loro MM. Chronotype and work shift in nursing workers of university hospitals. Rev Bras Enferm. 2017;70(5):958-64. [Thematic Edition “Good practices and fundamentals of Nursing work in the construction of a democratic society"] doi: 10.1590/0034-7167-2016-0542

34. Toaldo LFD, Xavier LPS, Ferla J. Interference of circadian rhythm of performance of nursing professionals. Rev Enferm UFPE. 2015;9(Suppl. 2):814-9. doi: 10.5205/reuol.6391-62431-2-ED.0902supl201506

35. Bargas EB, Monteiro MI. Factors related to absenteeism due to sickness in nursing workers. Acta Paul Enferm. 2014;27(6):533-8. doi: 10.1590/1982-0194201400087

36. Duclay E, Hardouin JB, Sébille V, Anthoine E, Moret L. Exploring the impact of staff absenteeism on patient satisfaction using routine databases in a university hospital. J Nurs Manag. 2015;23(7):833-41. doi: 10.1111/jonm.12219 
37. Santana LL, Sarquis LMM, Brey C, Miranda FMD, Felli VEA. Absenteeism due to mental disorders in health professionals at a hospital in Southern Brazil. Rev Gaúcha Enferm. 2016;37(1):e53485. doi: 10.1590/1983-1447.2016.01.53485

38. Roloff DIT, Cezar-Vaz MR, Bonow CA, Lautert L, Sant'Anna CF, Couto AM. Occupational health nurses: interdisciplinary experience in occupational health. Rev Bras Enferm. 2016;69(5):842-55. doi: 10.1590/0034-7167-2015-0113 